\title{
Nanofertilizers in Agriculture
}

\author{
Kaila Tara Meghana ${ }^{1 *}$, MD Wahiduzzaman ${ }^{1}$ and Golla Vamsi ${ }^{2}$ \\ ${ }^{1}$ Department of Agricultural Chemistry and Soil Science, Bidhan Chandra Krishi \\ Viswavidyalaya, India \\ ${ }^{2}$ Faculty of Forest Sciences and Forest Ecology, International Tropical Forestry \\ Program, Georg-August-Universität Göttingen, Germany \\ *Corresponding Author: Kaila Tara Meghana, Department of Agricultural \\ Chemistry and Soil Science, Bidhan Chandra Krishi Viswavidyalaya, India.
}

Received: December 08, 2020

Published: February 25, 2021

(C) All rights are reserved by Kaila Tara

Meghana., et al.

\section{Abstract}

Global population is rapidly increasing and is predicted to reach 9.6 billion by 2050 and the limited resources tend to push the sector forward demanding the development of a highly efficient agriculture thus allowing reduction of worldwide poverty and hunger [1]. To meet the food demands of this growing population the agriculture sector is being pressurized to assure food security. Hence chemical fertilizers are being considered as an inevitable source of plant nutrition for improving the crop production. This lead to a notion in farmers that using higher quantities of chemical fertilizers gains higher crop yields.

However, only less than half of the amount of applied fertilizers will be utilized by the crop whereas the remaining amount of fertilizer which is intended to be taken up by plant may get lost through leaching, become fixed in soil or contribute to water pollution which is even worse. According to recent statistical reports it has been observed that the key macronutrient elements Nitrogen, Phosphorous and Potassium applied to the soil are lost at a rate of $40-70 \%, 80-90 \%$ and $50-90 \%$, respectively, thus causing a considerable loss of applied resources [2]. Additionally, farmers tend to apply fertilizers repeatedly in order to achieve yields at desired levels, this overdose of chemicals counter acts and lead to decreased soil fertility and increased salt concentrations thereby causing future crop losses. Furthermore, irregular use of fertilizers without control on nutrient release patterns causes deterioration of product quality. Therefore, developing slow or controlled release fertilizers plays a crucial role not only in enhancing the crop production, productivity and quality, but also helps towards upgradation of sustainability in agricultural production. Given the unique properties of nanomaterilas such as high surface-to-volume ratio, controlled-release kinetics of nutrients to the targeted sites and sorption capacity, nanotechnology has a high importance for designing and using of new fertilizers. Nanofertilizers are nutrients encapsulated/coated with different types of nanomaterials for the control and slow delivery of one or more nutrients in order to satisfy the imperative nutrient requirements of plants [3]. These "smart fertilizers" are now being regarded as a promising alternative, to an extent that they are to be considered as preferred form of fertilizers over the conventional ones in several cases.

Keywords: Fertilizers; Nutrients; Leaching

\section{Introduction}

The current world population of 7.7 billion is predicted to increase to 8.5 billion by 2030, 9.7 billion in 2050 and 11.2 billion in
2100, according to UN DESA report. The present scenario thereby demands increased food production. If all of these people are to be fed sufficiently, total food consumption will have to be increased by $50-70 \%[4]$. 
After the introduction of fertilizer responsive and high yielding crop varieties, fertilizers are found to have a prominent role in improving the food production in developing countries especially [5]. Synthetic fertilizers greatly impact the world's food security and without which, there would be only half of the amount of food production that we are producing now [6]. "About 35-40\% of the crop productivity depends upon fertilizer" (Rameshaiah., et al. 2015). The applied fertilizers are also subjected to various types of losses such as leaching, volatilization, denitrification, fixation etc. (Shaoyu., et al. 2016) which reduces their efficiency. Based on recent fertilizer use efficiency studies it is identified that the efficiency of fertilizer nitrogen is only $30-40 \%$ in rice and $50-60 \%$ in other cereals, while the efficiencies of fertilizer phosphorus, Potassium and sulfur are $15-20 \%, 60-80 \%$ and $8-12 \%$ respectively in most of the crops Rakshit., et al. [2]. With regards to micronutrients, the efficiency of most of them is observed to be below $5 \%$. Therefore, there is an emergent necessity to adapt sustainable alternative strategies to enhance crop production.

\begin{tabular}{|l|c|c|}
\hline \multicolumn{1}{|c|}{ Nutrient } & Efficiency & Cause for low efficiency \\
\hline Nitrogen & $30-35 \%$ & $\begin{array}{c}\text { Immobilization, volatilization, } \\
\text { denitrification, leaching }\end{array}$ \\
\hline Phosphorous & $15-20 \%$ & Fixation in soils Al- P, Fe-P, Ca-P \\
\hline Potassium & $60-80 \%$ & Fixation in clay lattices \\
\hline Sulphur & $8-10 \%$ & $\begin{array}{c}\text { Immobilization, leaching with } \\
\text { water }\end{array}$ \\
\hline $\begin{array}{l}\text { Micronutrients } \\
\text { (Zn, Fe, Cu, Mn, } \\
\text { B) }\end{array}$ & $2-5 \%$ & Fixation in soils \\
\hline
\end{tabular}

Table a

Raising the rate of fertilizer utilization and reducing the contamination caused by illogical fertilization were the key steps for the sustainable development of agriculture. However, the progressional aims of the fertilizer were slow/controlled release, precision, and eco-environmental health in the world [7]. There has been an interest in the use of nanotechnology in agriculture for nearly 15 years (Rodrigues., et al.) identified various promising opportunities for applying nanotechnology to improve sustainable agri-food systems. Latest technologies such as controlled release technique and targeted delivery of agrochemicals (fertilizers and pesticides) for plant nutrition and pest control and thus, increase food safety and security and sensors for assessing specific conditions or analytes of interest in plant systems. Considering the resource use efficiency and safety, nanotechnology can precisely detect and deliver accurate quantity of nutrients to crop thereby reducing the residual effect in soil [8].

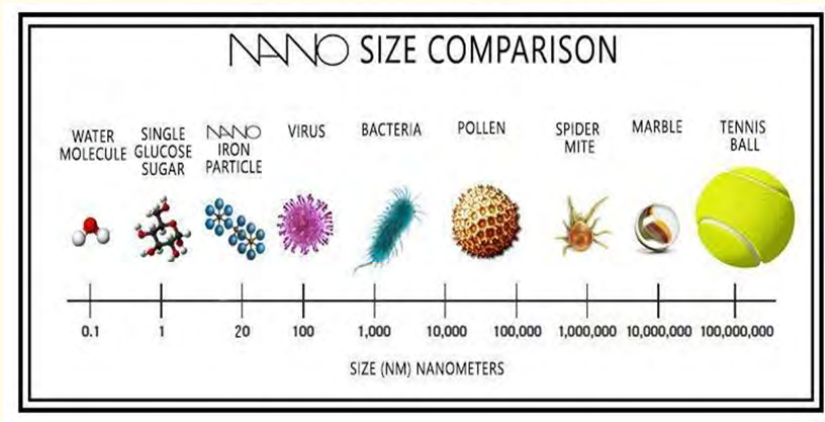

Figure a

\section{Nanofertilizers}

Nanomaterials which can supply one or more nutrients to the plants when are fortified with nutrients. The synthesis of nanofertilizers is done by fortification of nutrients with nano-dimension singly or in combination on to various adsorbent materials (Liu and Lal, 2015). Nano-fertilizer can be defined as nanoparticles encapsulated materials which slowly delivers nutrients to crops. Different kinds of encapsulation methods incclude: (a) encapsulation of nutrients with nanomaterials like nanotubes or nanoporous materials, (b) coating of nutrients with a thin protective layer of polymer and (c) formulations which can deliver nutrients as particles or emulsions of nanoscale dimensions $[9,10]$.

\section{Need for nanofertilizers}

Due to a great spectrum of challenges such as declining crop yields, reducing soil organic matter content, higher levels of multinutrient deficiencies, adverse climate, being faced by agriculture sector in production system.

Agricultural scientists are facing a wide spectrum of challenges in crop production system such as crop yield stagnation, declining organic matter, multi-nutrient deficiencies, climate change, shrinking primary agricultural resources such as arable land and water resources, resistance to Genetically Modified Organisms and 
deficit of labour. It is identified that crop production and productivity of most of the crops started to stagnate as a consequence of imbalanced fertilization and declining soil organic matter content. Overall consumption of total nutrients $\left(\mathrm{N}+\mathrm{P}_{2} \mathrm{O}_{5}+\mathrm{K}_{2} \mathrm{O}\right)$ increased by 2.9\% during 2018-19 over 2017-18 (FAI, 2018). According to studies in India, it is reported that the current ratio of NPK fertilizer utilization is being maintained at 10: 2.7: 1 against the optimal NPK fertilizer ratio of 4: 2: 1 which is ideal for crop productivity. It is very well known that Nitrogen fertilizers gets lost very rapidly in various pathways but leaching loss causes ground water pollution thus leas to eutrophication. There is a drastic decline in the fertilizer response ratio from $13.4 \mathrm{~kg}$ grain per one kilogram of nutrient applied in 1970's to $3.7 \mathrm{~kg}$ of grain in 2005 [11]. The percentage of crop loss is increasing every year nearing 25 to $30 \%$ due to great extent of multi-nutrient deficiencies which directly affect crop production. "The extent of nutrient deficiencies in the country are in the order of $89,80,50,41,49$ and $33 \%$ for $\mathrm{N}, \mathrm{P}, \mathrm{K}, \mathrm{S}, \mathrm{Zn}$ and $\mathrm{B}$, respectively" [8].

\section{Nanofertilizers for balanced crop nutrition Slow/controlled release fertilizers Nanoporus zeolites}

Zeolites are silicate minerals having some unique properties such as high specific surface area $\left(\approx 1150.5 \mathrm{~m}^{2} \mathrm{~g}^{-1}\right.$ ) and CEC (cation exchange capacity) 10 times more than that of soil, layered with honeycomb like crystal structure [12]. Its layered network is interconnected with tunnels and cages so this structure helps in loading with nutrients nitrogen and potassium. This nutrient loading can be done by combining the nutrients with other ingredients having slow rate of dissolution and containing elements like phosphorous, calcium and also trace nutrients [13]. The important advantages of Zeolite based nanofertilizers are it is capable of releasing the encapsulated nutrients very slowly thus making the nutrients available for plant uptake throughout the crop growing season [14].

Most of the studies have been conducted using zeolites loaded with cationic nutrients $\left(\mathrm{NH}_{4}{ }^{+}\right.$and $\left.\mathrm{K}^{+}\right)$as slow release fertilizers but for loading anionic nutrients zeolites should be modified thus the anionic nutrient loading is negligible. Based on the technique of surface modification, recently surfactants like hexadecyltrimethylammoniumbromide (HDTMABr) are used to modify the surface charge of zeolites which helps in easily imparting the anionic properties on the zeolitic surface $[15,16]$.
Li [17] demonstrated the possibility of using surfactant-modified zeolite using hexa decyltrimethylammonium as fertilizer carrier to control nitrate release, and deduced that surfactant-modified zeolite is a suitable sorbent for nitrate, since slow release of nitrate is achievable.

\section{Nanocomposites}

Nano-composites contain materials used to control the release of nutrients from synthetic fertilizers helping to enhance the fertilizer use efficiency and reducing the loss of applied nutrients. Application of nano composites proved to improve the fertilizer use efficiency as a result of physical and chemical properties adsorption and combination between nutrient elements and also due to higher reactivity. Nanocomposties act as a multifunctional fertilizer [7].

\section{Nanofertilizers in improving NUE}

Different crops have different nutrient requirements so nanofertilizers are synthesized to release nutrients which match the crop nutrient requirement. This can be achieved by coating the fertilizer particles with nano-membranes that helps in slow and steady release of nutrients. ${ }^{15} \mathrm{~N}$ examinations were accepted utilizing maize as a model framework have uncovered that $\mathrm{N}$-use effectiveness from nanofertilizer was $82 \%$ and the regular compost (urea) enlisted $42 \%$ with a net higher nitrogen-use productivity of $40 \%$ which is not really feasible in the ordinary framework. This recommends that nanofertilizers might be utilized as a system to control the keen arrival of supplements that similar with crop prerequisite [8].

Tremendous improvement of NUE was observed in plants after application of nanoparticles. In general, 3-4 times improvement in use efficiency was noticed for many nutrients including P, Zn, Fe and Mg nanoparticles [18]. Utilization of Nano-Phosphorous additionally helps in improving the organic acid concentration in the rhizosphere and Phosphorous take-up by the plants [19].

\section{Nanofertilizers in abiotic stress tolerance}

During the harvest development cycle, a plant needs to continually confront a few biotic and abiotic stresses. Dry spell, heat, salinity, waterlogging, and cold, among others, are major abiotic stresses that cause enormous crop loss to farming around the world by decreasing yield and crop quality ( $\mathrm{Wu}$ and $\mathrm{Ma}$, 2015). The part of nano-calcium (LITHOVIT ${ }^{\circledR}$ ), glycinebetaine (GB), acetylsalicylic 
acid (aspirin) and monopotassium phosphate fertilizers were assessed for mitigating salt pressure in Solanum lycopersicum, and it was discovered that LITHOVIT was the most effective in increasing the yield by $76 \%$ [20]. Utilizaton of nano silicon is found to be more effective and efficient compared to regular silicon application in alleviation of salinity stress [21].

A research study revealed the superiority of nano silicon over regular silicon on mitigation of stress damages which could have happened because of modifying the particles into to nano formulation can cause great changes in the physico-chemical properties of the particles as they possess higher surface [22].

Types of nanomaterials

- Carbon-based nanomaterials: These nanomaterials are composed mainly of carbon, commonly the forms are hollow spheres, ellipsoids, or tubes. Carbon based nanomaterials with spherical shape are called fullerenes and those with cylindrical shape are called nanotubes.

- Metal-based nanomaterials: These nanomaterials include quantum dots, Nano gold, and Nano silver and metal oxides, such as titanium dioxide, zinc oxide, magnesium oxide, iron oxide etc.

- Dendrimers: Dendrimers are Nano sized polymer of branched units with large number of chain ends on its surface. These can be altered into different ways to perform specific chemical functions which are intended to be done. Having this property dendrimers can be used as a catalyst and its three-dimensional structure with inner cavities allows us to use dendrimers for drug delivery by placing the drug molecules inside (Astruc., et al. 2010).

- Nanocomposites: A formulation obtained by combining nanoparticles with other nanoparticles or with larger bulktype materials is called nanocomposite. These are generally used to enhance mechanical, thermal barrier and flame-retardant properties of other materials (Ajayan., et al. 2003).

Unique properties of nanoparticles

- Smaller size, Larger surface area

- Increased surface area to volume ratio

- Nanoparticles are so small in size that they can even pass through the plant and animal cells, which is the main clue through which nanotechnologists able to achieve the phenomena of delivering the required product at cellular level, also this thing make nanotechnology advantageous over conventional method.

- Slow release

- $\quad$ Specific release

The nanoparticles have high specific surface area (SA) for their volume that a significant proportion of atoms of NP occur at surfaces which leads to higher reactivity of nanoparticles. This higher SA to volume ratio provides higher reactivity and better penetration into soil and plant [19].

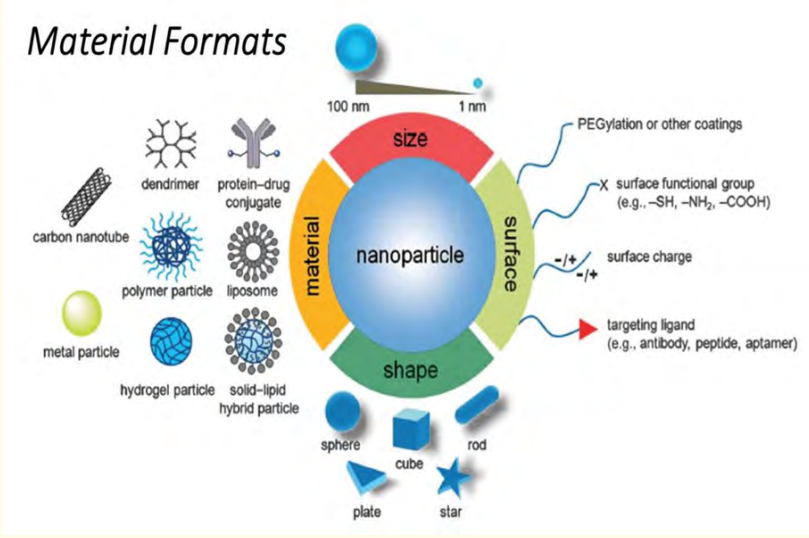

Figure b

\section{Synthesis of nanofertilizers}

Nanomaterials or nanoparticles for nanofertilizers can be synthesized by different approaches, top-down, bottom-up or using biological approaches. The top-down approach is based on the reduction of size to nanoscale well-organized assemblies from the bulk materials. Top-down is a physical method based on milling materials. The limitation in this approach is the low control in the size of nanoparticles and a greater quantity of impurities [8].

The bottom-up approach initiates at very basic level, using atomic or molecular level using chemical reactions to build up nanoparticles. Being a chemically controlled process, therefore, this approach has an advantage of controlling the particle size and reducing the impurities in a better way [1]. 

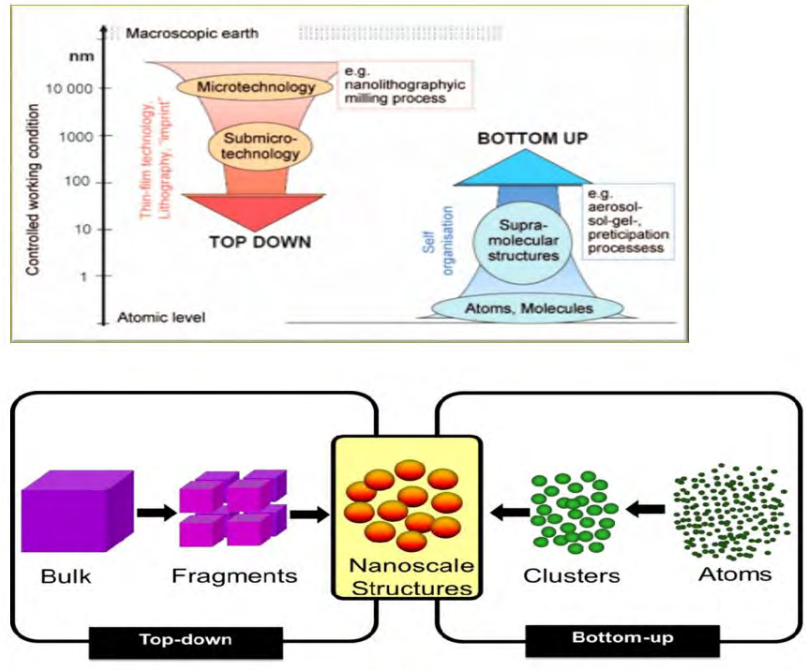

Figure c

\section{Nutrient loading}

Nanoparticles have higher efficiency to deliver nutrients to specific target sites in living systems. Nutrient loading on the nanoparticles is generally carried out by (a) attachment of nutrients on nanoparticles (b) adsorption of nutrients mediated by ligands on nanoparticles (c) encapsulation of nutrients with nanoparticulate polymeric shell (d) entrapment of polymeric nanoparticles (e) synthesis of nutrient nanoparticles [23].

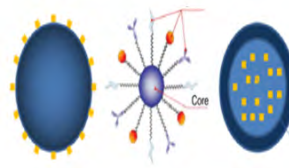

Entrapment of nutrients in nanoparticles

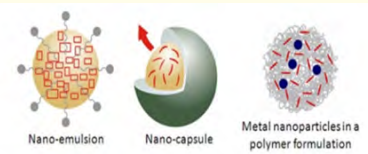

Encapsulation in polymeric shell
Figure d

\section{Methods of nanofertilizer application}

It can be applied by either foliar application or soil application. But studies are still being done to find out which method would be more efficient for nutrient utilization for different crops in different soil and environmental conditions.

Uptake and movement of nanoparticles

Nanoparticles can enter the plant system through different pathways root, shoot or leaf tissues (e.g., cuticles, trichomes, stomata, stigma, and hydathodes), even through wounds and root junctions also [24].

The pore diameter of the cell wall plays a major role in regulating the entry of nanoparticles through the cell wall $(5-20 \mathrm{~nm})$ (Fleischer., et al. 1999). Thus nanoparticles or nanoparticle aggregates with lesser diameter than the pore size of plant cell wall could easily enter through the cell wall and reach up to the plasma membrane [25].

Hence pore size is considered to be one of the main restrictions for passage of nanoparticle into the plant system. There are some studies which reported that the maximum dimension of nanoparticle that could be allowed to penetrate and accumulate inside the plant cells, usually ranges between $40-50 \mathrm{~nm}$ size hence this size range is called exclusion limit [26].

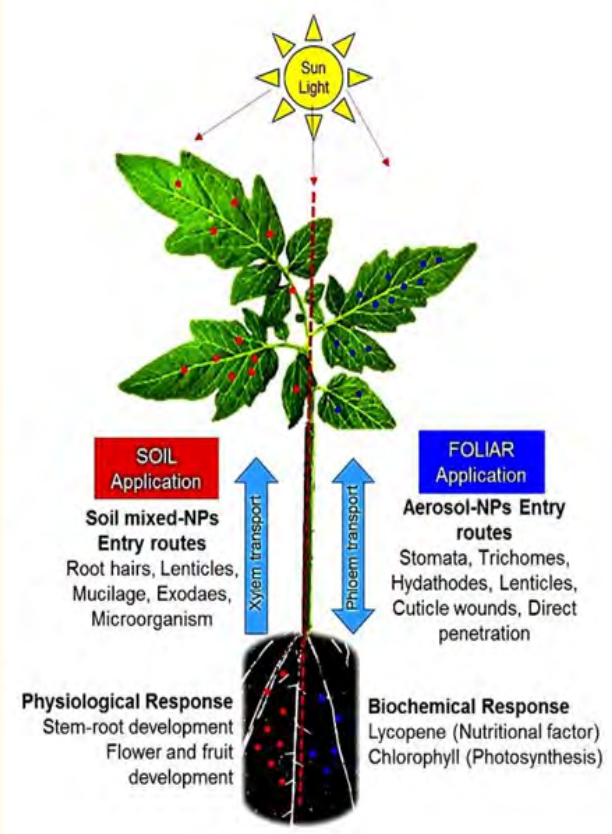




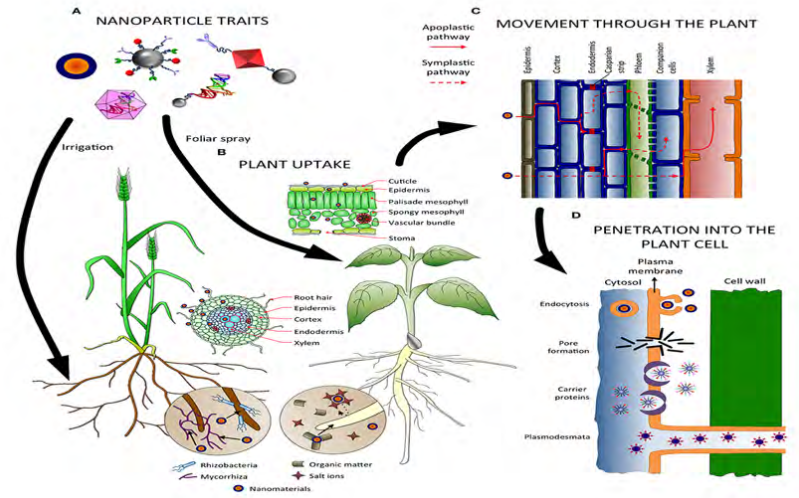

Figure e

Comparison of nanofertilizers with conventional fertilizers: [27]

\begin{tabular}{|c|c|c|}
\hline Properties & Nanofertilizers & $\begin{array}{c}\text { Conventional fertil- } \\
\text { izers }\end{array}$ \\
\hline $\begin{array}{l}\text { Solubility and } \\
\text { dispersion of } \\
\text { mineral nutri- } \\
\text { ents }\end{array}$ & $\begin{array}{l}\text { High solubility } \\
\text { and dispersion of } \\
\text { insoluble nutrients } \\
\text { in soil, increases } \\
\text { bioavailability }\end{array}$ & $\begin{array}{l}\text { Less bioavailability } \\
\text { to plants due to large } \\
\text { size and less } \\
\text { soluability }\end{array}$ \\
\hline $\begin{array}{l}\text { Nutrient } \\
\text { uptake } \\
\text { efficiency }\end{array}$ & $\begin{array}{l}\text { increased efficiency } \\
\text { and uptake ratio of } \\
\text { the soil nutrients }\end{array}$ & $\begin{array}{l}\text { Bulk composite is } \\
\text { very less available } \\
\text { and decrease } \\
\text { efficiency }\end{array}$ \\
\hline $\begin{array}{l}\text { Environmental } \\
\text { effects }\end{array}$ & $\begin{array}{l}\text { Less eco-toxicity } \\
\text { Safe (appropriate } \\
\text { measures to be } \\
\text { taken) } \\
\text { Easy mode of } \\
\text { delivery and } \\
\text { Disposal }\end{array}$ & $\begin{array}{c}\text { May produce toxic } \\
\text { effects }\end{array}$ \\
\hline $\begin{array}{l}\text { Controlled } \\
\text { release modes }\end{array}$ & $\begin{array}{l}\text { Both release rate and } \\
\text { release pattern is } \\
\text { precisely controlled }\end{array}$ & $\begin{array}{l}\text { Excess release of } \\
\text { fertilizers }\end{array}$ \\
\hline $\begin{array}{l}\text { Effective } \\
\text { duration of } \\
\text { nutrient } \\
\text { release }\end{array}$ & Extended & $\begin{array}{l}\text { Used by plants at the } \\
\text { time of delivery and } \\
\text { remaining are } \\
\text { converted as } \\
\text { insoluble salts in soil }\end{array}$ \\
\hline
\end{tabular}

\begin{tabular}{|l|c|c|}
\hline $\begin{array}{l}\text { Loss rate of } \\
\text { fertilizer } \\
\text { nutrients }\end{array}$ & $\begin{array}{c}\text { Reduce the loss by } \\
\text { leaching or leaking }\end{array}$ & $\begin{array}{c}\text { High losses through } \\
\text { leaching, drift, } \\
\text { fixation and runoff. }\end{array}$ \\
\hline $\begin{array}{l}\text { Cost of } \\
\text { fertilizer per kg }\end{array}$ & $\begin{array}{c}\text { Urea(46\% N) } \\
\text { nitrogen Rs. 240/- }\end{array}$ & $\begin{array}{c}\text {-Rs.5.52/- } \\
\text { DAP(,18\%N, 46\%P) } \\
\text { - Rs.22.54/- } \\
\text { MOP(60\%K) - Rs. } \\
16.05 /-\end{array}$ \\
\hline $\begin{array}{l}\text { Amount of } \\
\text { fertilizer } \\
\text { required per } \\
\text { acre(dose) }\end{array}$ & $\begin{array}{c}\text { According to IFFCO } \\
\text { replace } 45 \mathrm{~kg} \text { urea } \\
\text { bag. }\end{array}$ & $\begin{array}{c}\text { e.g: hybrid rice in } \\
\text { South India @ 175: } \\
60: 60 \mathrm{~kg} \text { NPK/ha }\end{array}$ \\
\hline $\begin{array}{l}\text { 10g nano Zn/ ha. } \\
\text { Accessibility }\end{array}$ & $\begin{array}{c}\text { Not yet available in } \\
\text { Indian markets }\end{array}$ & Very easily accessible \\
\hline $\begin{array}{l}\text { Government } \\
\text { subsidies }\end{array}$ & $\begin{array}{c}\text { Not yet implemented } \\
\text { any schemes as it is } \\
\text { still in experimental } \\
\text { condition. }\end{array}$ & $\begin{array}{c}\text { Fertilizers are } \\
\text { subsidized at }\end{array}$ \\
\hline
\end{tabular}

Table b

When comparing to chemical fertilizers requirement and cost, nano fertilizers are economically cheaper and are required in lesser amount [18].

Case study 1

Effect of nanoscale Zinc oxide particles on germination, growth and yield of groundnut

Zinc ( $\mathrm{Zn}$ ) is typically the second most abundant transition metal in organisms after iron and the only metal represented in all six enzyme classes (oxidoreductases, transferases, hydrolases, lyases, isomerases and ligases). Hence a study was conducted by Prasad., et al. on groundnut using zinc nanoparticles. Peanut seeds were treated with $\mathrm{ZnO}$ (nano $25 \mathrm{~nm}$ mean particle size) and chelated bulk $\mathrm{ZnSO}_{4}$ Separately then studies on seed germination, root growth, shoot growth, seedling vigor, chlorophyll content, flowering, pod yield were conducted.

Seed Vigor Index(SVI) $=$ Germination $\% \times($ root length + shoot length)

Treatment of nanoscale $\mathrm{ZnO}$ (25 nm mean particle size) at 1000 ppm concentration promoted both seed germination and seedling vigor and in turn showed early establishment in soil manifested by 
early flowering and higher leaf chlorophyll content. These particles proved effective in increasing stem and root growth (Table 1).

\begin{tabular}{|c|c|c|c|c|c|c|c|c|}
\hline \multirow{2}{*}{$\begin{array}{l}\text { Concent } \\
\text {-ration } \\
\text { (Zn in } \\
\text { ppm) }\end{array}$} & \multicolumn{2}{|c|}{$\begin{array}{c}\text { Germination } \\
(\%)\end{array}$} & \multicolumn{2}{|c|}{$\begin{array}{c}\text { Shoot } \\
\text { length }(\mathrm{cm})\end{array}$} & \multicolumn{2}{|c|}{$\begin{array}{c}\text { Root length } \\
(\mathrm{cm})\end{array}$} & \multicolumn{2}{|c|}{ SVI } \\
\hline & $\begin{array}{c}\text { Nano } \\
\text { ZnO }\end{array}$ & $\mathrm{ZnSO}_{4}$ & $\begin{array}{l}\text { Nano } \\
\text { ZnO }\end{array}$ & ZnSo & ${ }_{4} \begin{array}{l}\text { Nano } \\
\text { ZnO }\end{array}$ & ZnSO & $\begin{array}{c}\text { Nano } \\
\text { ZnO }\end{array}$ & $\mathrm{ZnSO}_{4}$ \\
\hline 400 & 90.33 & 84.01 & 6.60 & 3.80 & 11.52 & 5.84 & 1522.61 & 796.02 \\
\hline 1000 & 99.02 & 90.32 & 8.71 & 4.32 & 11.81 & 6.72 & 1701.33 & 910.36 \\
\hline 2000 & 96.04 & 88.75 & 4.94 & 3.76 & 9.42 & 8.06 & 1321.74 & 1195.72 \\
\hline Control & \multicolumn{2}{|c|}{85.3} & \multicolumn{2}{|c|}{3.11} & \multicolumn{2}{|c|}{5.02} & \multicolumn{2}{|c|}{693.6} \\
\hline
\end{tabular}

Table 1: Effect of nanoscale zinc oxide on seed germination and growth [28].
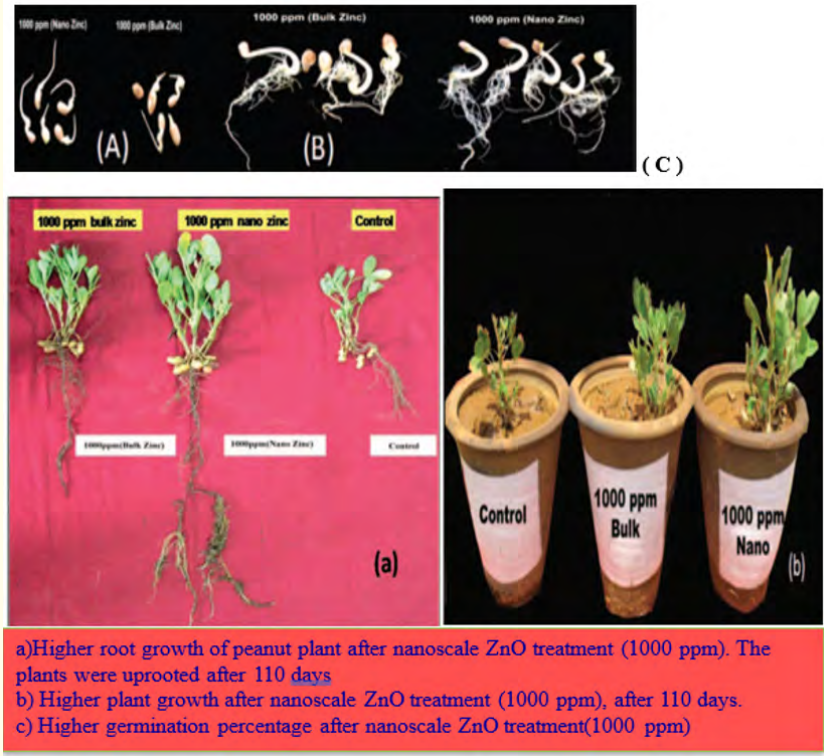

Figure f

From this study we can observe that the nanoscale zinc oxide which is used for seed treatment at $1000 \mathrm{ppm}$ concentration gave good seed germination, seedling vigor, shoot length and root length when compared to other treatments. The dose of $2000 \mathrm{ppm}$ nano $\mathrm{ZnO}$ did not give better results when compared to $1000 \mathrm{ppm}$ conc. which indicates that application of natrients in nanoparticulate form is undesirable.

\begin{tabular}{|l|c|c|c|}
\hline \multicolumn{1}{|c|}{ Treatment } & $\begin{array}{c}\text { No of pods } \\
\text { per plant }\end{array}$ & $\begin{array}{c}\text { 100 pod } \\
\text { weight } \\
\text { (gm) }\end{array}$ & $\begin{array}{c}\text { Pod yield } \\
\text { (Kg ha }^{-1} \text { ) }\end{array}$ \\
\hline Control & 9.2 & 77.27 & 2391.56 \\
\hline NPK+ ZnSO & 10.10 & 74.82 & 2410.82 \\
\hline NPK + Nano ZnO & 16.8 & 83.90 & 3121.54 \\
\hline CD @ 5\% LOS & 3.76 & 2.89 & 199.92 \\
\hline
\end{tabular}

Table 2: Effect of nanoscale zinc oxide and zinc sulphate on peanut yield [28].

Pod yield per plant was 34\% higher compared to chelated bulk $\mathrm{ZnSO}_{4}$.

Another study conducted by Prasad and co reported that foliar application of nanoscale $\mathrm{ZnO}$ at $2 \mathrm{~g} 15 \mathrm{~L}^{-1}$ significantly increased pod yield and shelling percent and other parameters as compared to Znso 4 as it is highly soluble and but fall off quickly.

It is observed that $30.5 \%$ higher pod yield was recorded with

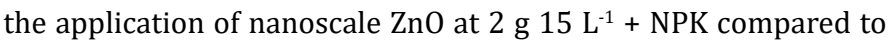
NPK alone and $29.5 \%$ higher pod yield compared to chelated zinc-

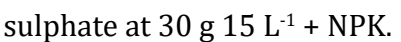

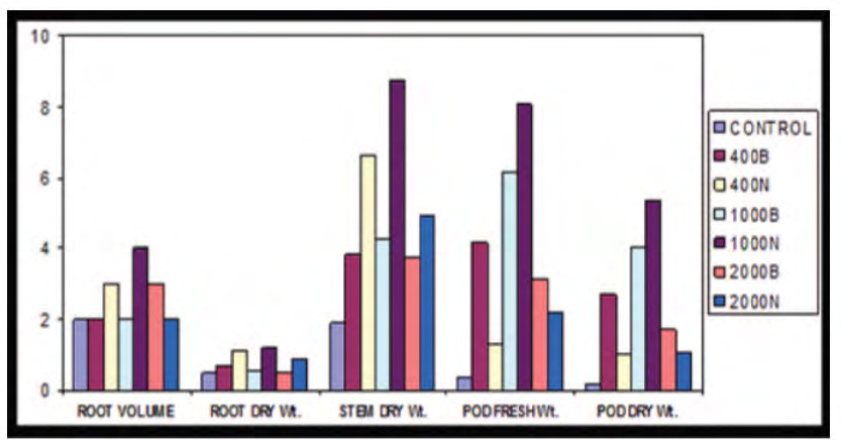

Figure g: Bar chart showing the effect of nano $\mathrm{ZnO}(\mathrm{N})$ and bulk $\mathrm{ZnSO}_{4}$ (B) concentrations on peanut plant root and shoot growth, pod yield [28].

Case study 2

Impacts of nano and non-nano fertilizers on productivity of potato

This experiment was conducted in Egypt by M.M.ABD ELAZEIM., et al. [29] at Minia University, El-Minia, Egypt. Agricultural 
sector in Egypt is captivated by shortage of arable land, limited water resources and soil infertility.

In this field experiment, nitrate ammonium $(33 \% \mathrm{~N})$, triple super phosphate $\left(15 \% \mathrm{P}_{2} \mathrm{O}_{5}\right)$ and potassium sulphate $\left(48 \% \mathrm{~K}_{2} \mathrm{O}\right)$ were used as resources for chemical fertilizers at the recommended level for potato crop at rates of 350 nitrogen, 85 phosphorus, and 200 potassium kgha-1 as recommended by the Egyptian Ministry of Agriculture, Egypt. Individual nano-N, nano-P and nano-K fertilizers in liquid formulations were imported from India containing $19 \%$ of each nutrient of NPK. These fertilizers are ecofriendly made through biological process, and have been designed to match chemical fertilizers in terms of nutrient content and application rates. These revolutionary nutritional agricultural inputs of nano- $\mathrm{N}$, nano-P and nano-K fertilizers are developed by private company (Pratishtha) in India in associationwith Indian Council of Agricultural Research as complete nutritional nanofertilizer of NPK for crops.

The obtained nitrogen size particles ranged from 5.78 to 9.33 $\mathrm{nm}$; 4.98 to $7.66 \mathrm{~nm}$ for phosphorus and 5.6 to $9.45 \mathrm{~nm}$ for potassium. The experimental actions followed during the course of this research have been conducted two methods of application (soil addition and foliar application) and comprised of four application rates in accordance with treatments described below. Agricultural activities other than above mentioned treatments were conducted according to potato cultivation recommendations of Agricultural Research Centre in Egypt [30].

The experimental location and site characteristics:

- Located at arid region $\left(28^{\circ} 18^{\prime} 16^{\prime \prime} \mathrm{N}\right.$ latitude and $30^{\circ} 34^{\prime} 38^{\prime \prime} \mathrm{E}$ longitude)

- Evaporation rate $>5000 \mathrm{~mm} /$ year

- Annual rainfall ranges from 2 to $23 \mathrm{~mm} /$ year

- Temperatures in winter varied from 5 to $20^{\circ} \mathrm{C}$ with extreme summer temperature $47^{\circ} \mathrm{C}$ in July (Egyptian Meteorological Agency).

- Clay texture

- $\mathrm{pH} 7.7$

- $\mathrm{EC1.35} \mathrm{dS} \mathrm{m}^{-1}$,

- $\quad$ CEC $37.87\left(\mathrm{cmol}_{\mathrm{c}} \mathrm{kg}^{-1}\right)$,

- Soil organic carbon (SOC) $18.48 \mathrm{~g} \mathrm{~kg}^{-1}$
- Classified as Alluvial soil according to Abd El-Azeim., et al.

The experimental treatments included therefore were as following:

- $\quad(\mathrm{T} 1)=100 \%$ NPK non-nano fertilizers, soil added at recommended level (control).

- $\quad(\mathrm{T} 2)=100 \%$ NPK nanofertilizers, soil added equal to recommended levels.

- $\quad(\mathrm{T} 3)=50 \%$ NPK nanofertilizers, soil added at half recommended level.

- $\quad(\mathrm{T} 4)=25 \%$ NPK nanofertilizers, soil added at quarter recommended level.

- $\quad(\mathrm{T} 5)=100 \%$ NPK non-nano fertilizers, foliar added at recommended level (control).

- $\quad(\mathrm{T} 6)=100 \%$ NPK nanofertilizers, foliar added equal to recommended levels.

- $\quad($ T7 $)=50 \%$ NPK nanofertilizers, foliar added at half recommended level.

- $\quad$ (T8) $=25 \%$ NPK nanofertilizers, foliar added at quarter recommended level.

Nitrogen nano or chemical fertilizer was soil or foliar applied in three equal portions, the 1st was applied after emergence, then two and four weeks later.

The rate of fertilizer application is:

$350 \mathrm{Kg} \mathrm{Nha}^{-1}$ - Ammonium nitrate $(34 \% \mathrm{~N})$-3splits $\left(1^{\text {st }}\right.$ - after seedling emergence,

$2^{\text {nd }}-2$ weeks after emergence, $3^{\text {rd }}-4$ weeks after emergence).

$85 \mathrm{~kg} \mathrm{P} \mathrm{ha}^{-1}$ - Triple super phosphate (46\% P, 12 -14\% Ca) basal application

$200 \mathrm{~kg} \mathrm{~K} \mathrm{ha}^{-1}$ - potassium sulphate $(48 \% \mathrm{~K}, 18 \% \mathrm{~S})$ - basal application

Based on these experiments the following data is observed.

$$
\text { NUE }=\quad \text { Tuber yield }\left(\mathrm{kg} \mathrm{ha}^{-1}\right)
$$




\begin{tabular}{|c|c|c|c|c|c|c|}
\hline \multirow{2}{*}{ Treatments } & $\mathbf{N}$ & $\mathbf{P}$ & $\mathbf{K}$ & & & \\
\hline & 2016 & 2017 & 2016 & 2017 & 2016 & 2017 \\
\hline $\begin{array}{l}100 \% \text { NPK } \\
\text { non-nano } \\
\text { (control) } \\
\left(\mathrm{T}_{1}\right)\end{array}$ & 60.42 & 61.17 & 248.79 & 251.88 & 105.74 & 107.05 \\
\hline $\begin{array}{l}\text { 100\% nano } \\
\text { NPK }\left(\mathrm{T}_{2}\right) \\
\end{array}$ & 58.31 & 59.09 & 240.09 & 243.32 & 102.04 & 103.41 \\
\hline $\begin{array}{l}50 \% \mathrm{NPK} \\
\text { nano }\left(\mathrm{T}_{3}\right)\end{array}$ & 51.73 & 53.95 & 213.02 & 222.16 & 90.54 & 94.42 \\
\hline $\begin{array}{l}25 \% \mathrm{NPK} \\
\text { nano }\left(\mathrm{T}_{4}\right)\end{array}$ & 40.62 & 41.25 & 167.27 & 169.84 & 71.09 & 72.18 \\
\hline $\begin{array}{l}100 \% \text { NPK } \\
\text { non-nano } \\
\left(T_{5}\right)\end{array}$ & 52.64 & 53.88 & 216.74 & 221.86 & 92.12 & 94.29 \\
\hline $\begin{array}{l}100 \% \mathrm{NPK} \\
\text { nano }\left(\mathrm{T}_{6}\right)\end{array}$ & 57.34 & 57.97 & 236.12 & 238.72 & 117.93 & 118.54 \\
\hline $\begin{array}{l}50 \% \mathrm{NPK} \\
\text { nano }\left(\mathrm{T}_{7}\right)\end{array}$ & 67.39 & 67.74 & 277.48 & 278.92 & 117.93 & 118.54 \\
\hline $\begin{array}{l}25 \% \mathrm{NPK} \\
\text { nano }\left(\mathrm{T}_{8}\right)\end{array}$ & 62.45 & 63.46 & 257.16 & 261.31 & 109.30 & 111.06 \\
\hline
\end{tabular}

Table 3: Nutrient use efficiency (Kg potato per Kg nutrient) (M.M.ABD EL-AZEIM., et al. 2019).

Nutrient uptake $\mathrm{kg} \mathrm{ha}^{-1}=$ Nutrient content $\%$ x Dry matter accumulation $\mathrm{kg} \mathrm{ha}^{-1}$ 100

\begin{tabular}{|c|c|c|c|c|c|c|}
\hline \multirow[t]{2}{*}{ Treatme } & \multicolumn{2}{|c|}{$\mathrm{N}\left(\mathrm{Kg} \mathrm{ha}^{-1}\right)$} & \multicolumn{2}{|c|}{ P $\left(\mathrm{Kg} \mathrm{ha}^{-1}\right)$} & \multicolumn{2}{|c|}{$\mathrm{K}\left(\mathrm{Kg} \mathrm{ha}^{-1}\right)$} \\
\hline & 2016 & 2017 & 2016 & 2017 & 2016 & 2017 \\
\hline $\begin{array}{l}100 \% \mathrm{NPK} \\
\text { non-nano } \\
\left(\text { control) }\left(\mathrm{T}_{1}\right)\right.\end{array}$ & 187.06 & 189.89 & 58.74 & 59.71 & 139.40 & 140.89 \\
\hline $\begin{array}{l}100 \% \text { nano } \\
\mathrm{NPK}\left(\mathrm{T}_{2}\right)\end{array}$ & 179.61 & 182.48 & 56.46 & 57.46 & 129.13 & 130.84 \\
\hline $\begin{array}{l}50 \% \text { NPK } \\
\text { nano }\left(\mathrm{T}_{3}\right)\end{array}$ & 156.98 & 164.56 & 49.71 & 51.28 & 113.09 & 118.56 \\
\hline $\begin{array}{l}25 \% \text { NPK } \\
\text { nano }\left(\mathrm{T}_{4}\right)\end{array}$ & 117.69 & 119.50 & 36.81 & 37.53 & 82.78 & 84.69 \\
\hline $\begin{array}{l}100 \% \mathrm{NPK} \\
\text { non-nano } \\
\left(\mathrm{T}_{5}\right)\end{array}$ & 159.28 & 163.24 & 50.16 & 51.55 & 114.27 & 118.00 \\
\hline $\begin{array}{l}100 \% \mathrm{NPK} \\
\text { nano }\left(\mathrm{T}_{6}\right)\end{array}$ & 175.40 & 177.59 & 54.70 & 55.56 & 128.82 & 131.84 \\
\hline $\begin{array}{l}50 \% \mathrm{NPK} \\
\text { nano }\left(\mathrm{T}_{7}\right)\end{array}$ & 211.76 & 212.87 & 65.51 & 65.59 & 162.77 & 165.71 \\
\hline $\begin{array}{l}25 \% \text { NPK } \\
\text { nano }\left(\mathrm{T}_{8}\right)\end{array}$ & 194.05 & 197.18 & 60.51 & 61.71 & 143.87 & 146.69 \\
\hline
\end{tabular}

Table 4: Potato tuber uptake and concentration of NPK. (M.M.ABD EL-AZEIM et al., 2019).

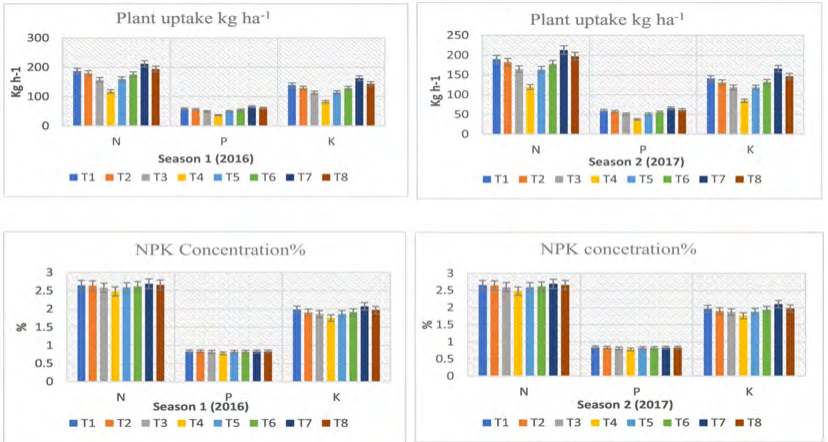

Figure h: Potato tuber uptake and concentrations of NPK (Kg ha $^{-1}$ ) as affected by NPK nano and non-nanofertilizers for both seasons [29].

Potato Harvest Index $\%=\frac{\text { Economic yield ton } \mathrm{ha}^{-1} * 100}{\text { Biological yield ton ha } \mathrm{ha}^{-1 *} 100}$

Net Revenue (EGP)

Benefit: Cost ratio $=\frac{\text { Cost of cultivation (EGP) }}{\text { Cot }}$

*1 Egyptian pound (EGP E£ ) = Rs. 4.46/-

\section{Results and Discussion}

From the data that has been obtained by field experiments the treatment 7 (50\% NPK nano) has given better results when compared to all other treatments in all parameters i.e., nutrient use efficiency, nutrient uptake, harvest index. net income etc., Hence this treatment is considered as best among all.

Merits of nanofertilizers

- Increased nutrient use efficiency

- Extended fertilizer release period

- Reduce the usage of chemical fertilizers by $50 \%$

- Nutrient mobilization increased by $30 \%$

- Increase in crop yield by $15-30 \%$

- Reduced soil toxicity

- Reduces frequency of application

- Minimise the effect of over dosage.

Demerits of nanofertilizers [1]

- Reactivity and variability is different under different conditions. 


\begin{tabular}{|l|c|c|c|c|c|c|c|c|}
\hline \multicolumn{2}{|c|}{ Treatments } & \multicolumn{2}{c|}{ Biological yield } & \multicolumn{2}{c|}{ Economic yield } & \multicolumn{2}{c|}{ Harvest index } & Application \\
\hline \% of RDF & & 2016 & 2017 & 2016 & 2017 & 2016 & 2017 & \\
\hline $\begin{array}{l}\text { 100\% NPK non- } \\
\text { nano (control) }\end{array}$ & $\mathrm{T}_{1}$ & 39.33 & 39.69 & 21.15 & 21.41 & 53.77 & 53.94 & Soil \\
\hline $100 \%$ nano NPK & $\mathrm{T}_{2}$ & 38.60 & 39.05 & 20.41 & 20.68 & 52.86 & 52.95 & Soil \\
\hline $50 \%$ NPK nano & $\mathrm{T}_{3}$ & 36.13 & 36.74 & 18.11 & 18.88 & 49.45 & 51.07 & Soil \\
\hline $25 \%$ NPK nano & $\mathrm{T}_{4}$ & 29.79 & 30.55 & 14.22 & 14.44 & 47.73 & 47.20 & Soil \\
\hline $\begin{array}{l}100 \% \text { NPK non- } \\
\text { nano }\end{array}$ & $\mathrm{T}_{5}$ & 35.96 & 36.51 & 18.42 & 18.86 & 51.22 & 51.65 & Foliar \\
\hline $100 \%$ NPK nano & $\mathrm{T}_{6}$ & 36.95 & 37.46 & 20.07 & 20.29 & 54.15 & 54.01 & Foliar \\
\hline $50 \%$ NPK nano & $\mathrm{T}_{7}$ & 39.81 & 40.31 & 23.59 & 23.71 & 59.24 & 58.81 & Foliar \\
\hline $25 \%$ NPK nano & $\mathrm{T}_{8}$ & 41.11 & 41.56 & 21.86 & 22.21 & 53.17 & 53.44 & Foliar \\
\hline
\end{tabular}

Table 5: Effects of nano and non-nano NPK fertilizers on harvest index of potato crop (M.M.ABD EL-AZEIM., et al. 2019).

\begin{tabular}{|l|c|c|c|c|c|c|c|}
\hline $\begin{array}{l}\text { Treat- } \\
\text { ments }\end{array}$ & $\begin{array}{c}\text { Cultivation } \\
\text { costs (EGP) }\end{array}$ & \multicolumn{2}{|c|}{$\begin{array}{c}\text { Total income } \\
\text { (EGP) }\end{array}$} & \multicolumn{2}{|c|}{$\begin{array}{c}\text { Net income } \\
\text { (EGP) }\end{array}$} & \multicolumn{2}{|c|}{$\begin{array}{c}\text { Benefit cost } \\
\text { ratio }\end{array}$} \\
\hline & & 2016 & 2017 & 2016 & 2017 & 2016 & 2017 \\
\hline $\mathrm{T}_{1}$ & 45,800 & 126882 & 128460 & 81082 & 82660 & 1.77 & 1.80 \\
\hline $\mathrm{T}_{2}$ & 50,800 & 122448 & 124092 & 71648 & 73292 & 1.41 & 1.44 \\
\hline $\mathrm{T}_{3}$ & 45,400 & 108642 & 113304 & 63242 & 67904 & 1.39 & 1.50 \\
\hline $\mathrm{T}_{4}$ & 42,700 & 85308 & 86616 & 42608 & 43916 & 1.00 & 1.03 \\
\hline $\mathrm{T}_{5}$ & 45,800 & 110538 & 113148 & 64738 & 67348 & 1.41 & 1.47 \\
\hline $\mathrm{T}_{6}$ & 50,800 & 120420 & 121746 & 69620 & 70946 & 1.37 & 1.40 \\
\hline $\mathrm{T}_{7}$ & 45,400 & 141516 & 142248 & 96116 & 96848 & 2.12 & 2.13 \\
\hline $\mathrm{T}_{8}$ & 42,700 & 131154 & 133266 & 88454 & 90566 & 2.07 & 2.12 \\
\hline
\end{tabular}

Table 6: Effect of nano and non-nano NPK fertilizers on potato relative economics for both seasons. (M.M.ABD EL-AZEIM., et al. 2019).

- This raises safety concerns for farm workers who may become exposed to xenobiotics during their application.

- It is reported that inhalation of nanoparticles during application caused chronic lung effects and exposure to metal based nanoparticles caused skin irritation,rashes, headaches. These include not only those exposed to nanofertilizer manufacturing but also nanofertilizer application in the field.

- The accumulation of nanoparticles in plants and potential health concerns.
- Some studies have reported phytotoxic effect of nanoparticles due to bioaccumulation.

\section{Conclusion}

- Nanofertilizers mainly delays the release of the nutrients and extends the fertilizer effect period. Obviously, there is an opportunity for nanotechnology to have a significant influence on energy, the economy and the environment, by improving fertilizers. Hence, nanotechnology has a high potential for achieving sustainable agriculture.

- $\quad$ Nano-fertilizers have opened up new opportunities to improve inputs use efficiency, minimize costs and environmental deterioration in some aspects.. Therefore, the scope for application of nanofertilizers in agricultural system needs to be prioritized in 21st century to accelerate the productivity of crops and sustain soil health and environmental quality through promoting use of nanoparticles in fertilizers and nano-sensors in soil microbial activity.

\section{Future Prospects}

Future studies must be focused on generating comprehensive knowledge in the following underexplored areas in order to introduce this novel frontier in sustainable agriculture.

- Nanofertilizer application safety and the study of the toxicity of different nanoparticles used for nanofertilizer production must be a research priority. 
- Evaluation of the effect of nanofertilizers in the soils with different physio-chemical properties is necessary in order to recommend a specific nanofertilizer for a specific crop and soil type.

- Biosynthesized nanoparticle based fertilizers and nanobiofertilizers should be explored further as a promising technology in order to improve yields while achieving sustainability

- Accumulation of NPs in edible parts of crops and bioavailability of the accumulated NPs to the next trophic level. In this regard, specific studies of NPs bioavailability in edible parts are urgently needed to use nanofertilizers safely.

- Understanding nanoparticles in agro-ecological ramification (plant specificity, dose dependency and bio toxicity)

- Physiological explanation of mechanism of uptake and translocation by plants

- Influence of nanoparticles in rhizosphere and on root surface

- Accounting possible interactions of nanoparticles with the biotic or abiotic environment and their possible amplified bioaccumulation effects

- Effect on environment and human health

- Minimising the residual effect

- Lab to land.

\section{Bibliography}

1. Zulfiqar Faisal., et al. "Nanofertilizer use for sustainable agriculture: Advantages and limitations". Plant Science (2019): 110270 .

2. Rakshit Rajiv., et al. "Customized fertilizers: Marker in fertilizer revolution". International Journal of Agriculture Environment and Biotechnology 51 (2012): 67-75.

3. P Solanki., et al. "Nano-fertilizers and their smart delivery system". Agriculture, in Nanoscience in Food and Agriculture (2016): 81-101.

4. FAO. (2012).

5. Naderi A., et al. "The role of nanotechnology in improving the use efficiency of nutrients and chemical fertilizers". Nanotechnology 11.12 (2013): 16-32.
6. Stewart WM and TL Roberts. "Food security and the role of fertilizer in supporting it”. Procedia Engineering 46 (2012): 76-82.

7. Liu Mingzhu. "Synthesis of a slow-release and superabsorbent nitrogen fertilizer and its properties". Polymers for Advanced Technologies 17.6 (2006): 430-438.

8. Subramanian KS and JC Tarafdar. "Prospects of nanotechnology in Indian farming". Indian Journal of Agricultural Sciences 81.10 (2011): 887-893.

9. DeRosa MR., et al. "Nanotechnology in fertilizers". Nature Nanotechnology 5 (2010): 91.

10. Nagula Sainath and PB Usha. "Application of Nanotechnology in Soil and Plant System with Special Reference to Nanofertilizers".

11. Biswas PP and PD Sharma. "A new approach for estimating fertiliser response ratio-the Indian scenario". Indian Journal of Fertilizers 4.7 (2008): 59.

12. Ditta Allah and Muhammad Arshad. "Applications and perspectives of using nanomaterials for sustainable plant nutrition". Nanotechnology Reviews 5.2 (2016): 209-229.

13. Chinnamuthu CR and P Murugesa Boopathi. "Nanotechnology and agroecosystem". Madras Agricultural Journal 96.1-6 (2009): 17-31.

14. Qureshi A., et al. "Nano-fertilizers: a novel way for enhancing nutrient use efficiency and crop productivity". International Journal of Current Microbiology and Applied Sciences 7.2 (2018): 3325-3335.

15. Bansiwal Amit Kumar., et al. "Surfactant-modified zeolite as a slow release fertilizer for phosphorus". Journal of Agricultural and Food Chemistry 54.13 (2006): 4773-4779.

16. Subramanian Kizhaeral S and M Thirunavukkarasu. "Nano-fertilizers and nutrient transformations in soil”. Nanoscience and Plant-Soil Systems. Springer, Cham (2017): 305-319.

17. Li Zhaohui., et al. "Removal of anionic contaminants using surfactant-modified palygorskite and sepiolite". Clays and Clay Minerals 51.4 (2003): 445-451. 
18. Manjunatha SB., et al. "Nanotechnology and its applications in30. Fahad S Hussain., et al. "Potential role of phytohormones and agriculture: A review". Journal of Farm Science. plant growth-promoting rhizobacteria in abiotic stresses: consequences for changing environment". Environmental Science and Pollution Research 22.7 (2015): 4907-4921. ence (2015): 775-807.

20. Tantawy AS., et al. "Nano silicon application improves salinity tolerance of sweet pepper plants". International Journal of ChemTech Research 8.10 (2015): 11-17.

21. Tarafdar JC., et al. "Nanotechnology: interdisciplinary science of applications". African Journal of Biotechnology 12.3 (2013).

22. Singh Ashok K., et al. "Microwave synthesis of silver nanofluids with polyvinylpyrrolidone (PVP) and their transport properties". Colloid and Polymer Science 286.14-15 (2008): 16671673.

23. Day JK., et al. "Nanotechnology and its importance in micronutrient fertilization". International Journal of Current Microbiology and Applied Sciences 7.5 (2018): 2306-2325.

24. Wang Peng., et al. "Nanotechnology: a new opportunity in plant sciences". Trends in Plant Science 21.8 (2016): 699-712.

25. Navarro Enrique., et al. "Environmental behavior and ecotoxicity of engineered nanoparticles to algae, plants, and fungi". Ecotoxicology 17.5 (2008): 372-386.

26. Sabo-Attwood Tara., et al. "Uptake, distribution and toxicity of gold nanoparticles in tobacco (Nicotiana xanthi) seedlings". Nanotoxicology 6.4 (2012): 353-360.

27. Cui HX., et al. "Applications of nanotechnology in agrochemical formulation, perspectives, challenges and strategies". International conference on Nanoagri, Sao pedro, Brazil, 20-25 June (2010).

28. Prasad T N V K V., et al. "Effect of nanoscale zinc oxide particles on the germination, growth and yield of peanut". Journal of Plant Nutrition 35.6 (2012): 905-927.

29. MM Abd El-Azeim., et al. "Impacts of nano- and non-nanofertilizers on potato quality and productivity". Acta Ecologica Sinica 40.5 (2016): 1-13. 